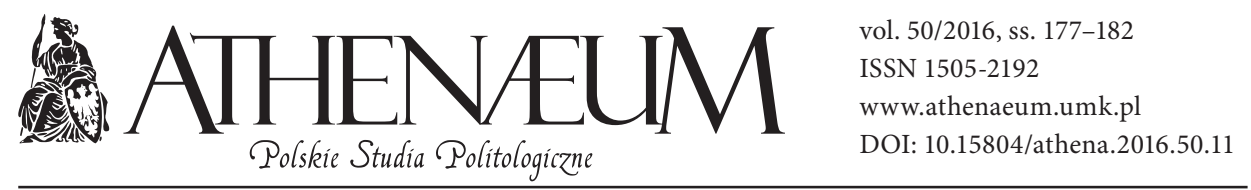

\title{
Arkadiusz Nyzio, Rządzić znaczy służyć? Historia Unii Demokratycznej (1991-1994), Wydawnictwo PiT, Kraków 2014, ss. 595
}

\section{Arkadiusz Lewandowski*}

Z perspektywy 25 lat, które minęly od kontraktowych wyborów z czerwca 1989 roku, można zaryzykować tezę, że pierwsza dekada Trzeciej Rzeczypospolitej to czas poszukiwań instytucjonalnych form dla uprawiania demokratycznej polityki, czego jednym $\mathrm{z}$ istotnym elementów było formowanie partii politycznych. Dla polityków wywodzących się z „Solidarności” był to swoisty test $\mathrm{z}$ umiejętności radzenia sobie $\mathrm{w}$ demokratycznym systemie politycznym. Partyjne rozdrobnienie, jakie powstało w Sejmie w wyniku pierwszych w pełni demokratycznych wyborów parlamentarnych, oraz wyniki elekcji z 1993 roku pokazują, jak trudny był to okres na naukę. Symboliczne jest to, że żadne, poza Sojuszem Lewicy Demokratycznej i Polskim Stronnictwem Ludowym, ugrupowanie będące wówczas w parlamencie dziś albo nie ist-

* Państwowa Wyższa Szkoła Zawodowa w Płocku, Instytut Nauk Humanistycznych i Społecznych. nieje, albo nie bierze udziału w rzeczywistej rywalizacji politycznej.

W latach 90. XX wieku w Polsce funkcjonowało kilka ugrupowań, które stanowiły punkty orientacyjne na mapie polskiej polityki. Do grona tych najważniejszych należy zaliczyć m.in.: Zjednoczenie Chrześcijańsko-Narodowe, Porozumienie Centrum, Kongres Liberalno-Demokratyczny, Polskie Stronnictwo Ludowe, Sojusz Lewicy Demokratycznej (początkowo jako sojusz partii lewicowych) oraz oczywiście Unię Demokratyczną (później Unię Wolności). I właśnie ostatniej z wymienionych partii została poświęcona recenzowana tu książka.

Na rynku wydawniczym w ostatnich latach coraz częściej pojawiają się prace poświęcone partiom politycznym Trzeciej Rzeczypospolitej. Zainteresowanie tym zagadnieniem przejawiają przeważnie młodzi badacze (historycy, politolodzy, socjologowie) poszukujący w wydarzeniach lat 90. XX wieku źródeł dla skutecznej analizy obecnej rywalizacji politycznej w Polsce. 
Wyjątkowym zainteresowaniem cieszy się środowisko, które w ostatnich latach ostatniej dekady XX w. funkcjonowała pod nazwą Unia Wolności. Jego naukowa atrakcyjność udokumentowana zostało $\mathrm{m}$. in. przez recenzowaną tu pracę autorstwa Arkadiusza Nyzio, która dopełnia swoją tematyką dwie inne książki wydane w 2010 roku, a mianowicie książkę Marii Wincławskiej: Unia Wolności. Partia polityczna $w$ okresie transformacji oraz pracę Karoliny Chimiak: ROAD. Polityka czasu przełomu. Ruch Obywatelski Akcja Demokratyczna 1990-1991.

Arkadiusz Nyzio w swojej pracy za obszar badania przyjął nie tylko konkretne ugrupowanie polityczne, ale jak sam zasugerował, UD potraktował zarówno jako partię polityczną istniejącą w określonym czasie, ale także środowisko polityczne „wykraczające zarówno poza partyjne ramy instytucjonalne, jak i poza przyjęte ramy chronologiczne" (Nyzio, 2014).

Przyjęcie tej optyki wymagało od autora odpowiedniej selekcji i doboru źródeł oraz umiejętności umieszczania konkretnych wydarzeń związanych z Unią Demokratyczną w określonym kontekście historycznym. Arkadiusz Nyzio, absolwent politologii i europeistyki na Uniwersytecie Jagiellońskim, przedstawiciel młodego pokolenia polskich badaczy doskonale sobie z tym zadaniem poradził. Autorowi udało się w sposób skuteczny umiejscowić Unię Demokratyczną w przestrzeni politycznych przemian i tworzącej się nad Wisłą nowej politycznej rzeczywistości. Można stwierdzić, iż Nyzio popełnił książkę o kulisach polskiej polityki pierwszych lat III RP; politycy Unii Demokratycznej to bowiem główni bohaterowie najważniejszych wydarzeń z początkowego okresu transformacji. By użyć zdania z samej książki, UD była „partią, która wyrosła z kompromisu Okrągłego Stołu i której zasadniczym celem politycznym stało się przekucie jego postanowień $\mathrm{w}$ aksjologiczny fundament konstytuujący niepodległą Polską" (Nyzio, 2014).

Książka jest pracą historyczną, a nie np. politologiczną, co we wstępie pracy uzasadnia sam autor. Bynajmniej nie jest to zarzut a jedynie informacja, $z$ jakim profilem pracy naukowej mamy do czynienia. Nie rozważa zatem Nyzio np. problemu procesu instytucjonalizacji Unii Demokratycznej, jej ewentualnej programowej lewicowości lub prawicowości, a poświęca swoją książkę opisowi procesu powstania, istnienia i zakończenia życia konkretnej partii politycznej, koncentrując się na jej „okołoparlamentarnej" aktywności.

Cel badań został określony we wstępie pracy i dotyczył wskazania na „przyczyny i konsekwencje sukcesów i porażek UD, widzianych przez pryzmat słabości aksjologicznych i instytucjonalnych z jakimi obecnie boryka się polska polityka" (Nyzio, 2014). Nyzio dookreśla swoje zamierzenia, sugerując, iż celem, jaki mu przyświeca, jest zbadanie pełnej historii Unii Demokratycznej, ze szczególnym uwzględnieniem jej specyficznego podejścia do uprawiania polityki, nazywanego „etosem”.

Niestety brak w książce szerszego potraktowania samego zagadnienia etosu, 
operacjonalizacji tego pojęcia jako kategorii obecnej w polityce, które przecież zostało zaproponowane jako element głównego problemu badawczego. Mógłby autor odnieść się chociażby do książki Sławomira Drelicha, który z pojęcia etosu uczynił główną kategorię swojej książki poświęconej populistom z Samoobrony (Drelich, 2010). W ramach omawianej tu pracy Czytelnik musi zadowolić się jedynie kilkoma zdaniami objaśniającymi, czym ów etos jest. Z kart książki otrzymujemy zatem informacje, że etos na potrzeby pracy rozumiany jest jako etos solidarności, oznaczający idee współpracy, jedności i pokojowego nastawienia. W etosie, jak sugeruje autor, tkwi klucz do zrozumienia siły i słabości Unii i to poprzez pojęcie etosu można wytłumaczyć najważniejsze decyzje podejmowane przez liderów tej partii.

Przyjęta przez autora koncepcja pracy determinuje jej rzeczywiste ramy chronologiczne. Opisana geneza środowiska UD, będąca tematem pierwszego rozdziału, obejmuje zatem okres lat 70. i 80. XX wieku i początki ruchów oraz organizacji opozycji antykomunistycznej, w których swoją działalność polityczną rozpoczynali późniejsi politycy Unii Demokratycznej.W ten sposób Nyzio, co wydaje się zasadne, stara się określić uwarunkowania biograficzne, które determinują, model i styl polityki uprawianej przez polityków UD.

Kolejne rozdziały pracy koncentrują się już na powstaniu Unii Demokratycznej (rozdział II „Formowanie Unii Demokratycznej"), jej funkcjonowaniu w bieżącej polityce (rozdział III „Unia Demokratyczna w poszukiwaniu miejsca na scenie politycznej” i rozdział IV „Pod znakiem rządu Hanny Suchockiej), jej ostatniemu etapowi istnienia, czyli przekształceniu w Unię Wolności (RozdziałV „Unia Demokratyczna ku nowej formule") oraz dalszym losom środowiska Unii Demokratycznej (rozdział VI). W tych esencjonalnych rozdziałach książki rozmywa się główny problem badawczy, jaki chciał rozstrzygnąć autor. Czytając książkę, można bowiem odnieść wrażenie, że zagadnienie etosu jest jedynie uzupełnieniem historii UD, a nie głównym problemem, pod kątem którego autor analizował funkcjonowanie środowiska omawianej przez siebie partii. Powyższa uwaga w żaden jednak sposób nie deprecjonuje jakości samej zawartości książki, która emanuje rzetelnością, skrupulatnością oraz wyczuciem tematu prezentowanym przez autora.

Książka Rzadzić znaczy służyć. Historia Unii Demokratycznej (1991-1994) ukazuje i uwypukla to, co niestety jest bolączką współczesnej polityki, a mianowicie pokazuje, że polityczna rzeczywistość a obraz tworzony przez partyjne i medialne narracje, a w ślad za nimi przez dyskurs publiczny, częstą nie są ze sobą nawet styczne. Przewijająca się przez kolejne strony książki historia animozji i niechęci, jaka istniała pomiędzy Tadeuszem Mazowieckim a Bronisławem Geremkiem, czy też opowiadanie się tego drugiego za tzw. „przyspieszeniem” z perspektywy dzisiejszych politycznych sporów i narracji mogą nieco dziwić lub też 
wręcz zaskakiwać. Praca Arkadiusza Nyzio pełna jest tego typu „odczarowañ” ówczesnej politycznej rzeczywistości. Autor rekonstruuje i przedstawia Czytelnikowi nastroje wewnątrz UD i rzeczywiste przesłanki decyzji podejmowanych przez polityków tej partii. Pokazuje także skalę podziałów, jakie trapiły Unię oraz jak wpływały one na stabilność samej partii. Nie ulega bowiem wątpliwości, iż UD towarzyszył ten sam problem co większości ówczesnych partii politycznych, czyli niski poziom instytucjonalizacji i ich „rozdemokratyzowanie”.

Na poparcie swoich tez Nyzio wskazuje nie tylko wypowiedzi poszczególnych polityków, ale również analizuje wyniki badań prowadzonych przez Mirosławę Grabowską i Tadeusza Szawiela dotyczących poglądów politycznych członków partii politycznych. W przypadku UD kluczowe było współistnienie wewnątrz UD frakcji wywodzących się Forum Prawicy Demokratycznej (FPD) oraz Ruchu Obywatelskiego - Akcji Demokratycznej (ROAD) - dwóch partii, które współtworzyły UD i ich podziałów na tle np. poglądów dotyczących roli Kościoła w systemie politycznym (,ideologiczna dwubiegunowość").

Inną cechą charakterystyczną dla ówczesnego okresu w polskiej polityce, na którą zwrócił uwagę Nyzio, jest kwestia przynależności partyjnej, o której decydowały często nie kwestie poglądów, ale historyczne, towarzyskie i personalne doświadczenia. Prezentuje ten proces na przykładzie FPD oraz ROAD, gdzie - jak podaje -„o przynależności do Forum i Ruchu kwestie ideolo- giczne czy aksjologiczne decydowały w co najwyżej trzeciorzędnym stopniu" (Nyzio, 2014). Ważniejsze wg autora książki były więzi oraz kontakty towarzyskie z okresu PRL i związane z nimi doświadczenia oraz stosunek do rządu Tadeusza Mazowieckiego jak i osoby samego premiera.

Czynnikiem, który według autora mógł przyczynić się do takich, a nie innych losów UD, było poczucie elitarności, zauważalne już w kampanii prezydenckiej Tadeusza Mazowieckiego i obecne praktycznie w całej historii środowiska Unii. Swoisty elitaryzm trafnie oddaje przytoczony przez autora fragment jednego $\mathrm{z}$ artykułów prasowych oceniający wybory prezydenckie z roku 1990: „Sztab Mazowieckiego żył atmosferą wiosny 1990, kiedy to za premierem stanęły elity, a więc stanął i naród, no bo gdzie indziej miał stanąć" (Nyzio, 2014). Powyższa opinia oraz informacje o działaniach takich jak niepublikowanie nieprzychylnych sondaży przez „Gazetę Wyborczą”, ponieważ redaktor naczelny tej gazety uznał, „że to po prostu niemożliwe" pokazują, z jakim stanem samooceny środowiska UD mieliśmy do czynienia. Szukając wsparcia dla zrozumienia współczesnej polityki, uzasadnione wydaje się porównanie $\mathrm{z}$ kampanią wyborczą $\mathrm{w}$ roku 2015 prowadzoną przez Bronisława Komorowskiego, otoczonego przez polityków byłej Unii Demokratycznej. To samo przekonanie o własnej fachowości, o swoistej intelektualnej przewadze nad politycznymi przeciwnikami, ale także nad społeczeństwem zaprowadziło zarówno Unię Wol- 
ności, następczynię Unii Demokratycznej do upadku, jak i Bronisława Komorowskiego do przegranej w prezydenckiej elekcji.

Ta swoista rekonstrukcja „udeowskiego" stylu myślenia zawierającego w sobie element etosu wydaje się być jedną z głównych zalet książki. Ten styl myślenia jest bowiem obecny również we współczesnej polskiej polityce, i jak się okazuje, ma nadal wpływ na wyborcze wyniki. Dzięki tej książce możemy zrozumieć, czemu projekt Unii Demokratycznej nie odniósł spektakularnego sukcesu i czemu do chwili obecnej środowisko to skutecznie nie odrodziło się jako nowa partia polityczna.

Nyzio ukazuje również problem, jaki dla polityków UD niosło ze sobą założenie o potrzebie działania zgodnego $\mathrm{z}$ etosem. Często uniemożliwiało ono polityczne działania, jak np. zawiązanie koalicji z SLD w 1993 r. Ten wyjątkowy styl uprawiania polityki wpływał również na relacje $\mathrm{z}$ innymi partiami postsolidarnościowymi, na które UD w pewnym momencie się „obraziła", a momentami stawał się tylko polityczną deklaracją (jak np. w momencie przyznania premii członkom rządu Hanny Suchockiej).

Myślenie w kategoriach etosu było również grzechem pierworodnym Unii Demokratycznej i dotyczyło procesu powołania partii politycznej. Ten projekt polityczny był realizowany bowiem bez entuzjazmu liderów politycznych tego środowiska. Nyzio sugeruje, że „mająca powstać za moment partia była więc już na wejściu postrzegana jako pewna konieczność dziejowa - trzeba było ją stworzyć, zarówno ze względów politycznych, jak i moralnych, ale w wypowiedziach jej liderów próżno szukać szczególnego entuzjazmu z tego powodu" (Nyzio 2014). Powstaje zatem naturalne pytanie, co było spoiwem UD. Według autora recenzowanej tu pracy tym łącznikiem było podzielane przez liderów środowiska misyjne pojmowanie polityki, wspólne spojrzenie na dorobek opozycji demokratycznej i Okrągłego Stołu oraz udział $\mathrm{w}$ „wojnie na górze”.

Oceniając pracę jako całość, należy podkreślić, iż jest to monografia, która powinna stać się podstawową literaturą dla politologów i historyków zajmujących się najnowszą historią polityczną naszego kraju, jak i współczesną polską sceną polityczną. Całościowa historia Unii Demokratycznej przedstawiająca takie obszary jak działalności w parlamencie, w grach wyborczych, kampaniach wyborczych oraz w grach koalicyjnych, została napisana przez prezentującego wysokie umiejętności autora, który w syntetyczny sposób rekonstruuje okres aktywności Unii Demokratycznej w polskiej polityce.

Każda z płaszczyzn partyjnej aktywności omawianej w książce jest analizowana wieloaspektowo i szczegółowo. Ponadto Nyzio przedstawia wiele interesujących, dotąd nieeksplorowanych wątków z działalności Unii, jak np. zagadnienie finansów partii.

$\mathrm{W}$ interesujący sposób analizowane są przez autora m.in. wyniki osiągane przez UD w poszczególnych wyborach. Poza podaniem wyborczego poparcia, Nyzio proponuje Czytelnikowi także własne wnioski 
dotyczące startu partii w wyborach, prowadzenia kampanii wyborczej oraz błędów, jakie popełniano, jak np. nieumiejętnego obsadzania list wyborczych przez politycznych liderów.

Godne podkreślenie są takie walory książki jak wielość źródeł, w tym również tych wywołanych, z których autor potrafil wyselekcjonować istotne informacje. Warto też pochwalić autora za formułowanie oryginalnych wniosków, które świadczą o szerokiej wiedzy z zakresu najnowszej historii Polski i umiejętności analitycznego myślenia. Często na łamach książki Nyzio dyskutuje z funkcjonującymi już w literaturze opiniami, co ważne, argumentując rzeczowo swoje stanowisko.

Zaletą książki są również przypisy, w ramach których autor obszernie rozszerza wątki poboczne pojawiające się na stronach książki. Jest to korzystne dla Czytelnika, który niekoniecznie dobrze orientu- je się w meandrach polskiej polityki okresu pierwszej fazy transformacji politycznej. Brakuje natomiast w książce, co zostało już wcześniej zasygnalizowane, wyodrębnionej części (np. podrozdziału) podsumowującej temat znaczenia etosu dla działalności Unii Demokratycznej. Odniesienie się do głównego problemu uczyniłoby książkę jeszcze ciekawszą. Niemniej jednak wartość, jaką omawiana praca wnosi do nauk o polityce, jest niezaprzeczalna.

\section{BibLIOGRAFIA:}

Drelich, S. (2010). Populistów ethos zmanipulowa$n y$. Toruń: Wydawnictwo Uniwersytetu Mikołaja Kopernika.

Nyzio, A. (2014). Rządzić znaczy stu̇̇yć? Historia Unii Demokratycznej (1991-1994). Kraków: Wydawnictwo PiT. 